\title{
OLGA NIKOLAEVA
}

\section{REVIEW: ROAD TRANSPORT \\ AS THE KEY SOURCE OF ENVIRONMENTAL POLLUTION IN CITIES, AND THE ASSOCIATED HUMAN HEALTH RISKS}

Olga V. Nikolaeva, Candidate of Biological Sciences, Senior Researcher, EducationalExperimental Soil-Ecological Center, Lomonosov Moscow State University; Chashnikovo, Solnechnogorsk Region, 141592, Russian Federation, tel.: +7 (926) 588-33-98

E-mail: olgamsu@yandex.ru

\section{Abstract}

Road transport is a necessary attribute of urban environment. Fuel vehicles emit a great variety of pollutants, transform the environment and pose human health risks. This problem is highly recognized in the EU and US, while it is out of sufficient attention in other countries.

This review article highlights road traffic as the key source of environmental pollution in cities and the associated adverse effects on human health. This problem is reviewed in details and possible solutions related traffic management, fuel quality increase and roadside territories design are described.

Takeaway for practice: This article is written for educational purposes to direct the attention of academia, government and businesses to road traffic as the key source of environmental pollution in the urban environment. It is especially useful for urbanists considering the negative effects of motor vehicles for human well-being in sustainable city planning.

Key words: road transport; transport-related contaminants; environmental pollution; adverse health effects; city; urban area

Citation: Nikolaeva O. (2018) Review: Road Transport as the Key Source of Environmental Pollution in Cities, and the Associated Human Health Risks. Urban Studies and Practices, vol. 3, no 3, pp. 25-35. DOI: https://doi.org/10.17323/usp33201825-35

Introduction $^{1}$

$\mathrm{T}$ The idea for this article originated in communication with Moscow students of different institutes and specialties. They said that industrial plants and factories were the key source of environmental pollution in the city; road transport was not considered. This stereotype may come from the time when motorization was low. The author aims to break this misunderstanding and highlight road traffic as the key source of urban environmental pollution and adverse effects on human health.

1 The author thanks Igor Nikolaev for the considering this article and his precious comments; Alice Nikolaeva for the general support; and Sophia Lisovitskaya for Fig. 1 creation.
About $55 \%$ of the Earth's population is urban and this proportion is expected to grow to $70 \%$ by 2050 [United Nations, 2014]. Due to strong demand for mobility in cities, urbanization is accompanied by an increase of the number of vehicles. In 2014, there were 1.2 billion vehicles on the road and 2 billion are expected by 2035 [Green Car Report, 2014].

Numerous studies worldwide conducted at the end of the 20th century revealed the extent of environmental pollution and associated adverse health effects caused by traffic. The close proximity of people and transport in urban areas is a cause for concern. Vehicles exhausts being originated at the near ground level strongly affect the pedestrians. 
Road transport is responsible for $57-75 \%$ of total emissions in urban areas [WHO, 2005] and it was recognized as the key source of environmental pollution. The contribution of traffic in total emissions in million-inhabitant cities is estimated to be significantly higher. For example, $80 \%$ of all emissions to the atmosphere in Moscow relate to auto transport and only a minor part goes to industry. The hot-spots of transport-related exposure in cities are roads and roadside territories.

\section{Transport-related Contaminants}

Road traffic releases a wide spectrum of contaminants harmful for the environment and human health: polycyclic aromatic hydrocarbons (PAH), heavy metals (HM), petroleum hydrocarbons $(\mathrm{PH})$, nitrogen oxides $\left(\mathrm{NO}_{\mathrm{x}}\right)$, carbon oxides (CO and CO2), volatile organic compounds (VOCs) and ozone $\left(\mathrm{O}_{3}\right)$. Pollutants are emitted into the environment in the processes of fuel combustion; loss of lubricating oil, fuel, coolants and car cleaning products; corrosion of vehicles and the road itself. The application of deicing salts (DS) on roads also contributes environmental pollution. A brief description of the pollutants is given below.

PAH are hazardous environmental pollutants of recognized carcinogenic, mutagenic, and teratogenic effect [Grimmer, 1983]. Due to their low solubility and high hydrophobicity, PAH have low degradation rates and accumulate in soils for many years [Lu et al., 2007]. The key source of PAH related to traffic is the incomplete combustion of fossil fuels. Additional emissions of PAH occur as a result of the abrasion of rubber tires, road surfaces, and brake linings [Takada et al., 1991]. 16 individual PAHs are currently of top priority for environmental monitoring in the US and EU [US EPA, 2014], while only 1 is monitored in Russia.

HM cause blood, neurological, respiratory, and cancer disease [Laumbach, Kipen, 2012]. These contaminants cannot be degraded by microorganisms and are highly persistent in the urban environment. They are mainly released from the corrosion of radiators and brakes $(\mathrm{Cu})$, tire dust $(\mathrm{Zn})$, and fuel combustion $(\mathrm{Pb})$ [Van Bohemen, Van de Laak, 2003].

One of the most toxic $\mathrm{HM}$ is $\mathrm{Pb}$. It was actively applied worldwide as a fuel additive to prevent uncontrolled fuel combustion. The recognition of its harmful effects led to the ban of its use. Leaded fuel was forbidden in the last decades of 20th century in US and EU, and in 2003 it was banned in Russia (Federal Law of the Russian Federation № 34 [2003]). Being very resistant in the environment $\mathrm{Pb}$ may be present in soils for hundreds of years. In 2016, we revealed a significant increase of the permissible levels of mobile $\mathrm{Pb}$ in Moscow roadside soils [Nikolaeva et al., 2017]. This is a significant risk to people in the vicinity of roads as wind flows can disperse soil particles in the air which people can inhale. $\mathrm{Pb}$ can affect the nervous, cardiovascular, immune and reproductive systems. Children under five and pregnant women are especially sensitive to this exposure. $\mathrm{Pb}$ is known to have negative neurological effects, cause brain damage and decrease children's intellectual development; it causes problems in fetal development, premature birth and even stillbirth; $\mathrm{Pb}$ exposure in adults is attributed mainly to cardiovascular system damage. The ways of exposure are the inhalation of polluted air or incidental swallowing of dust particles from contaminated foodstuffs.

PH are the main components of automobile fuels. They reflect the general technogenic load on soils [Gennadiev et al., 2015].

The application of DS also contributes to environmental pollution, causing plant tissue necrosis [Gałuszka et al., 2011]. The high solubility of DS in water minimizes ecological risk by means of their washing out of the soil.

$\mathrm{NO}_{\mathrm{x}}$ : The most dangerous and active gas within nitrogen oxides group is $\mathrm{NO}_{2}$. It is emitted into the atmosphere directly from the burning of car fuel. $80 \%$ of the $\mathrm{NO}_{2}$ originating in cities comes from motor vehicle exhausts [Australian Government, 2005]. Irritating airways in the human respiratory system, this gas reduces resistance to respiratory diseases, particularly asthma. Such effects as coughing, wheezing or difficulty breathing often appear [USEPA, 2018]. Pedestrians walking near roads, and drivers, have the highest risk of $\mathrm{NO}_{2}$ exposure although its concentration decreases significantly with distance. The environmental effect of $\mathrm{NO}_{2}$ relates to its role as the precursor for acid rains, smog and ozone formation.

CO is one of the most toxic air pollutants. $60 \%$ of the annual global emissions of CO into the atmosphere originate from vehicle exhausts due to incomplete combustion of fuels [WHO, 2000]. CO affects humans by binding onto hem proteins in the blood, reducing its oxygen-carrying capacity and causing tissue hypoxia. According to WHO, the organs and tissues suffering the 
most are the brain, the cardiovascular system, exercising skeletal muscle, as well as developing fetuses. Patients with cardiovascular disease are expected to be particularly sensitive to $\mathrm{CO}$. Exposure to this gas can cause headaches, and high levels of CO may lead to dizziness, nausea, vomiting, coma and death. In conditions of heavy traffic drivers may be under the risk of reduced coordination. The most dangerous road locations are within tunnels where the ventilation is poor. On open roads CO concentrations rapidly decrease from road to rooftop. Within $100 \mathrm{~m}$ of the road its concentration may reach background levels. Higher CO concentrations are found on the downwind side of street canyons. Among air pollutants of very high concentrations, carbon monoxide causes a large number of accidental deaths.

$\mathbf{C O}_{2}$ is the major greenhouse gas on the Earth. Urban road traffic is a significant source of world $\mathrm{CO}_{2}$ emissions, contributing $10 \%$ of all European $\mathrm{CO}_{2}$ emissions. $\mathrm{CO}_{2}$ emission by vehicles is an obvious result of fuel combustion. Despite the $\mathrm{CO}_{2}$ level along roads being higher than further away locations, its concentration in the air does not usually exceed permissible levels due to the ventilation effect.

Traffic related VoCs are represented by alkanes, alkenes and aromatic hydrocarbons. VOCs may affect the human nervous and sensory systems, cause damage to organs and lead to allergies. These compounds do not have acute toxic effects but their effect appears with longterm exposure. One of the most harmful VOCs is benzene, known to be carcinogenic. Benzene is a marker of transport-related air pollution in general [WHO, 2005]. VOCs are of high environmental interest as they promote ozone and smog formation, participating in photochemical reactions in atmosphere [US EPA, 2014].

$\mathbf{O}_{3}$ is not primary pollutant emitted by vehicles. It originates in the air when $\mathrm{CO}, \mathrm{NO}_{\mathrm{x}}$, VOCs reacts with ultraviolet radiation. It is recognized as a region-wide air pollutant due to easy transport over long distances. High concentrations of ground level $\mathrm{O}_{3}$ promote respiratory diseases.

Road traffic is also a key source of noise pollution in cities and is studied together with air, water and soil pollution. Numerous studies have shown that in addition to hearing loss, noise exposure leads to changes in the heart rate, blood pressure and the release of stress hormones that affect the metabolism. The probability of strokes, diabetes mellitus and diseases of the nervous system increases [Babisch, 2002; Enda,
Owen, 2018]. At least one million disabilities per year occur in Europe because of the increased noise impact on people [WHO, 2011].

Thus, motor transport leads to the multiple contamination of the environment and is associated with a complex of adverse health effects which may be of synergetic character. Environmental contamination is associated with biodiversity loss, lower rates of growth and development, and the destabilization of ecosystems.

\section{Pathways and Distribution Patterns of Traffic- related Pollutants Released into the Environment}

Contaminants may be transported through the environment bound to dust particles, in the form of aerosols or in a gaseous state. Particulate or dissolved pollutants are transferred into the environment via aerial transport or the infiltration of road runoff and spray waters [Werkenthin et al., 2014]. World health and environmental organizations pay a great deal of attention to particles with a diameter of less than $10 \mathrm{mi}$ crometers (PM10) and less than 2.5 micrometers (PM2.5) as these particles can easily be inhaled. The finest fractions of dust particles are especially important for monitoring as they cannot be sedimented due to air fluctuations near roads and their concentrations are growing. In periods of dry weather, PM concentrations in the air may reach critical values and are reduced only with rain.

The distribution patterns of pollutants in the environment depend on a complex of factors: climatic conditions, landscape, vegetation type, road configuration, type of road surface, traffic intensity, vehicle types, driving style. The development of models to predict the release and distribution of transport-related contaminants in the environment is the most complicated for the urban environment as building-related characteristics strongly affect the contaminants spread specific.

According to average estimations, traffic-related contaminants concentrations in the air are generally most intense in the $0-300 \mathrm{~m}$ zone either side of major roads with 4 lanes of intense traffic [US EPA, 2014]. This area is reported as the risk zone for human well-being. Prior to soil pollution the contaminated area is usually within 0-50 m zone from the road as the gas components do not affect soils significantly. The major soil pollutants are HM, PAH, PH, and DS (Fig. 1).

Living, working and studying close to major roads promotes respiratory diseases, allergies 


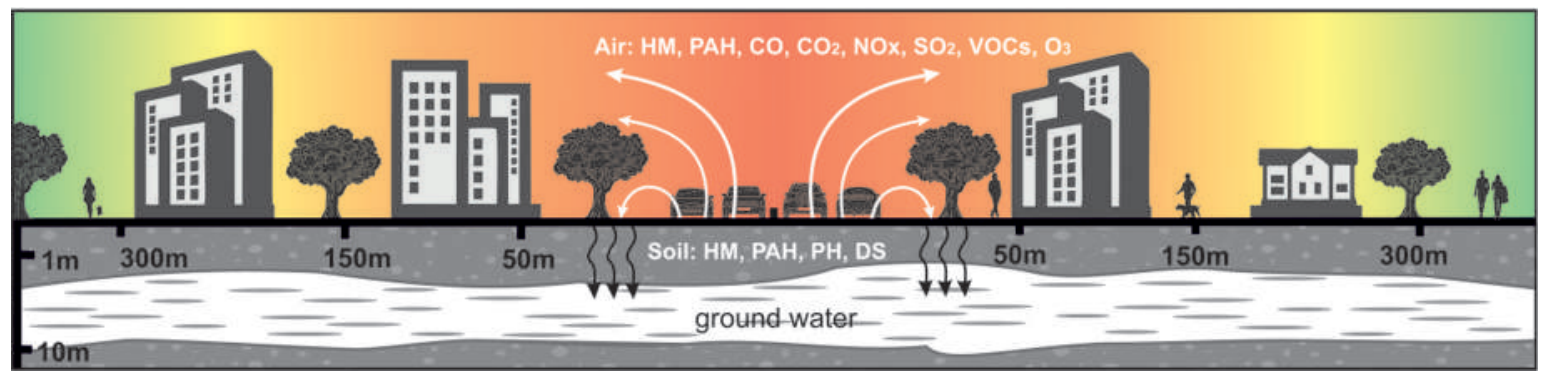

The concept @) Olga Nikolaeva; design and realization @ Sophia Lisovitskaya

Fig. 1. Pathways of transport-related pollutants release to the environment: red - high, yellow - medium, green background levels of environmental pollution

and asthma, cardiovascular diseases and is associated with an increase in cancer rates and premature death [Vette et al., 2013; Raaschou-Nielsen et al., 2012]. According to Chen et al. [2017], a higher incidence of dementia was reported for people living within 1-300 $\mathrm{m}$ of roadside zones. Despite air pollution, negative health effects are related to road noise causing damage to the nervous and cardiovascular systems and promoting chronic disease. The American Lung Association [2018] report about 30-45\% of the urban population in North America are affected by road pollution. These values for large cities are expected to be higher.

The highest risk of transport-related contaminant exposure is to drivers, children, the elderly and people in poor health. Creating public zones along major roads should be avoided. Kindergartens, playgrounds, schools located within 300 $\mathrm{m}$ of the roadside can seriously harm children's health (Fig. 2).

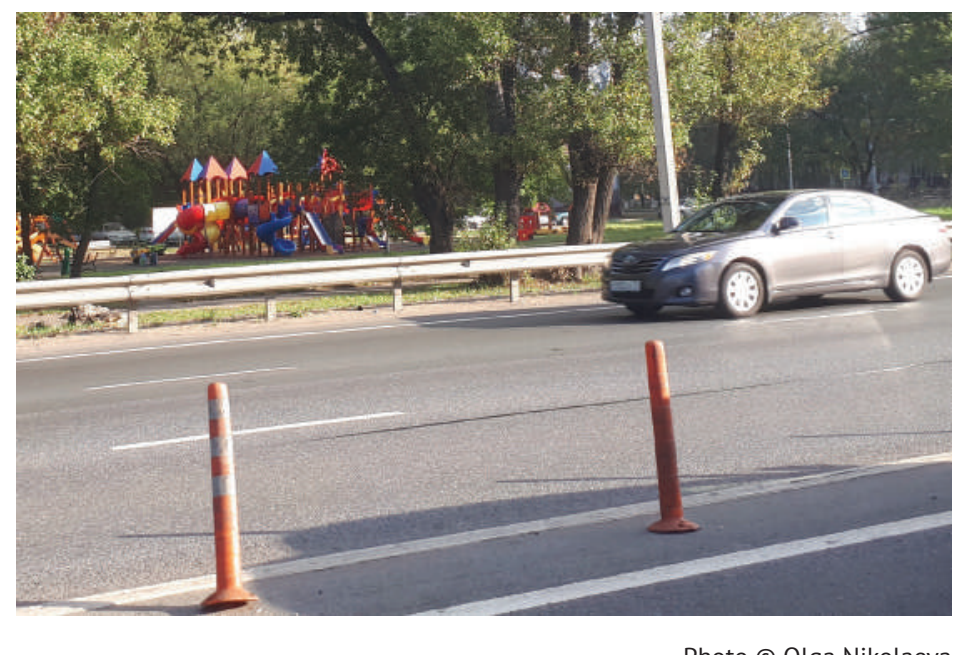

Fig. 2. Example of playground associated with high risk to children's health
Thus, road transport contaminates the environment at the system level affecting air, soil and water systems through direct pollution or via contaminants infiltrating ground waters. Pollution levels in the vicinity of roads are significantly higher compared to other urban areas creating high human exposure risk.

\section{Solutions for Mitigation of Transport-related Pollutants}

The recognition of traffic-related negative effects to human health in the US and EU has been raised in academic research, government decisions and activities on finding methods to reduce this exposure.

\section{Regulation of Vehicle Emissions}

The continuous implementation of more environmentally friendly fuels and engine technologies contributes to the improvement of the ecological situation in cities. Each new standard (Euro \#) requires lower emissions. At the moment Euro 6 is in use (Table 1) in Europe, and Euro 5 in Russia. Russia implemented Euro 5 in 2016.

Table 1 shows the evolution of fuels lowers the pollutant emissions rates. The implementation of new standards and the related increase in fuel quality reduced contaminant emissions from 1980 until 2004 tenfold [WHO, 2005]. One of the challenges for the future is to continue decreasing PM emissions.

\section{Traffic management}

Speed regulation. Depending on the driving pattern, the volume and content of vehicle exhaust differs. Maximal Emissions rates are char- 
Table 1. European Union standards for passenger cars [DieselNet, 2018]

\begin{tabular}{|c|c|c|c|c|c|c|c|}
\hline \multirow[t]{2}{*}{ Stage } & \multirow[t]{2}{*}{ Date } & CO & HC & HC+NOx & NOx & PM & \multirow{2}{*}{\begin{tabular}{|l|} 
PN \\
$\# / k m$
\end{tabular}} \\
\hline & & \multicolumn{5}{|l|}{$g / k m$} & \\
\hline \multicolumn{8}{|c|}{ Positive Ignition (Gasoline) } \\
\hline Euro $1^{\dagger}$ & 1992.07 & $2.72(3.16)$ & - & $0.97(1.13)$ & - & - & |- \\
\hline Euro 2 & 1996.01 & 2.2 & - & 0.5 & - & - & - \\
\hline Euro 3 & 2000.01 & 2.30 & 0.20 & - & 0.15 & - & - \\
\hline Euro 4 & 2005.01 & 1.0 & 0.10 & - & 0.08 & - & - \\
\hline Euro 5 & $2009.09^{b}$ & 1.0 & $0.10^{\mathrm{d}}$ & - & 0.06 & $0.005^{e, f}$ & - \\
\hline Euro 6 & 2014.09 & 1.0 & $0.10^{\mathrm{d}}$ & - & 0.06 & $0.005^{e, f}$ & $6.0 \times 10^{11 e, 9}$ \\
\hline \multicolumn{8}{|c|}{ Compression Ignition (Diesel) } \\
\hline Euro $1^{\dagger}$ & 1992.07 & $2.72(3.16)$ & - & $0.97(1.13)$ & - & $0.14(0.18)$ & - \\
\hline Euro 2, IDI & 1996.01 & 1.0 & - & 0.7 & - & 0.08 & сфк- \\
\hline Euro 2, DI & $1996.01^{a}$ & 1.0 & - & 0.9 & - & 0.10 & - \\
\hline Euro 3 & 2000.01 & 0.64 & - & 0.56 & 0.50 & 0.05 & - \\
\hline Euro 4 & || 2005.01 & 0.50 & |- & 0.30 & 0.25 & 0.025 & |- \\
\hline Euro 5a & $2009.09^{b}$ & 0.50 & - & 0.23 & 0.18 & $0.005^{f}$ & - \\
\hline Euro 5b & $2011.09^{c}$ & 0.50 & - & 0.23 & 0.18 & $0.005^{f}$ & $6.0 \times 10^{11}$ \\
\hline Euro 6 & 2014.09 & 0.50 & - & 0.17 & 0.08 & $0.005^{f}$ & $6.0 \times 10^{11}$ \\
\hline
\end{tabular}

* At the Euro $1 . .4$ stages, passenger vehicles > 2,500 kg were type approved as Category $\mathrm{N}_{1}$ vehicles.

$\dagger$ Values in brackets are the conformity of production (COP) limits.

a Until 1999.09.30 (after that date DI engines must meet the IDI limits).

b 2011.01 for all models.

c 2013.01 for all models.

${ }^{d}$ And $\mathrm{NMHC}=0.068 \mathrm{~g} / \mathrm{km}$.

e Applicable only to vehicles using DI engines.

f $0.0045 \mathrm{~g} / \mathrm{km}$ using the PMP measurement procedure.

${ }^{9} 6.0 \times 10^{12} 1 / \mathrm{km}$ within first three years from Euro 6 effective dates.

acterized for the lowest and the highest mean vehicle speeds. Moderate speed is the most environment friendly approach. The elimination of traffic jams which cause the dirtiest stop-start driving and regulating maximum speeds will help to improve ecological situation.

Banning trucks in urban areas. The heavier the vehicle, the more exhaust it emits and diesel cars produce more contaminants than petrol ones. Minimizing trucks in urban areas may be a good solution. Roads for heavy vehicle flows ideally should go out of towns.

Regulating of the age of vehicles. The older the vehicle, the more pollutants it produces. Age-related vehicle taxes may be a good measure in this case.
Travelling distance optimization. Creating a smart road network in the city may decrease average travelling distances and emissions of contaminants.

Alternative transport use. One alternative is the electric car. The key advantage of electric vehicles is significantly lower contaminants and noise pollution. Due to the absence of exhaust, electric vehicles produce only non-exhaust PM emissions: HM are attributed to the corrosion of car bodies, and PAH are related to abrasion of tires and road surface. The emission level reduction in this case is about $70 \%$ compared to regular transport. The main challenges for this development are increases in battery efficiency and the creation of charging infrastructure. 

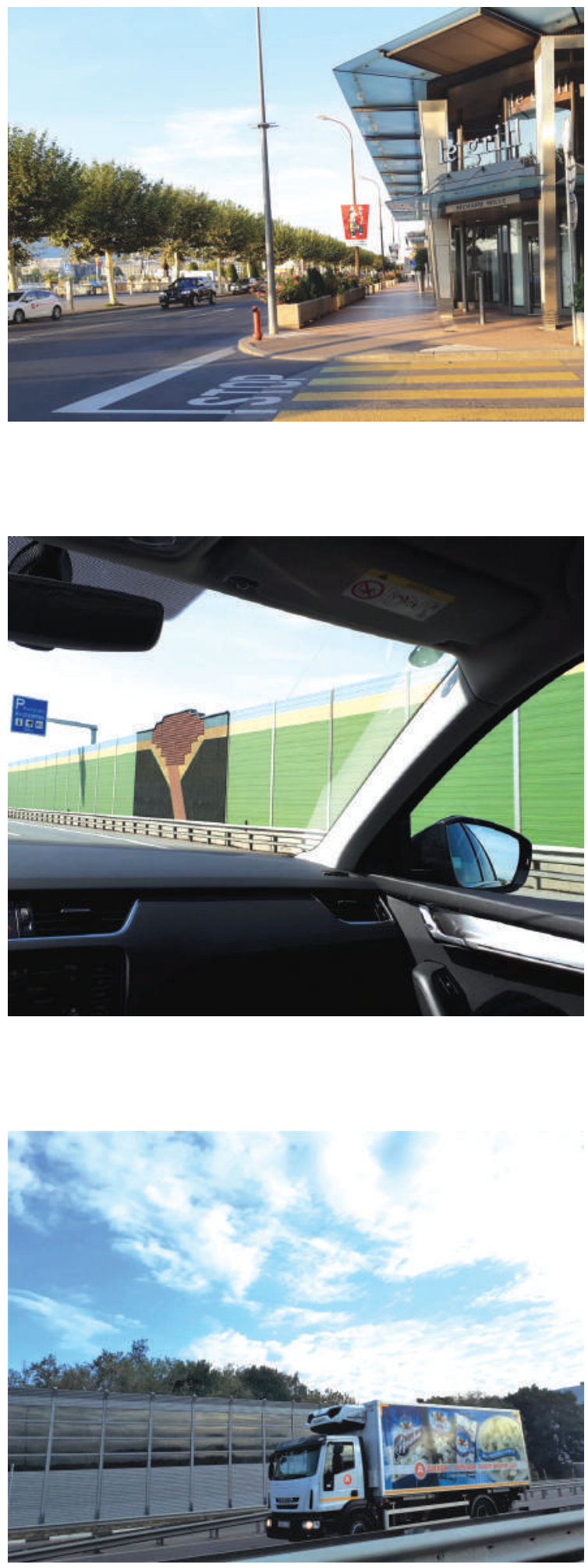

Photos (c) Olga Nikolaeva, Igor Nikolaev

Fig. 3. Types of roadside barriers left to right: vegetation barriers, solid barriers, solidvegetation barriers
Another option is hybrid electric transport. Its advantage compared to the electric car is the production of electricity aboard the vehicle. There is a combination of internal combustion engine and electric motor with the battery. This vehicle requires lower fuel and may emit $50 \%$ lower contaminants compared to regular fuel transport. Hybrid electric transport is of high use in Japan.

The bicycle is the cheapest and the most ecologically friendly option. The challenge for the big cities is the creation of safe routes for cyclists.

There are different outlooks on the future of transport, but the most likely perspective for the coming 20-30 years according to WHO [2005] is the predominance of conventional petrol and diesel engines.

Reduction in vehicle numbers. A reduction in the number of vehicles is an actual trend in the developed countries. The recognition of traffic emissions has led to the priority of public transport and a decrease of personal transport use. For example, WHO [2005] reported that the implementation of separate bus lanes in Paris improved traffic circulation and decreased transport-related emissions by $2-10 \%$ for nitrogen oxides, carbon monoxide and PM10. Higher taxes for private cars, paid parking, city centers without cars can make a city more comfortable for pedestrians and cyclists.

There is a large potential decrease of transport-related pollution. A complex of different measures in urban environments may be an effective instrument for the improvement the quality of urban life.

\section{Roadside barriers}

A recognized "right now" method to reduce the negative effect of traffic to people living near busy roads is the creation of roadside barriers. For effective urban planning solutions, the proper design of barriers should be considered. Figure 3 shows key types of roadside barriers: vegetation barriers; solid barriers; and combinations of solid and vegetation barriers.

Green barriers. The implementation of vegetation barriers along roads is regular practice to support ecological and human comfort. Plants filter out airborne particles using their foliage and absorb different gases, mainly $\mathrm{CO}$ and $\mathrm{CO}_{2}$. In addition to air cleaning, plants provide many other benefits to the urban environment [Forman, 2014]. They regulate the microclimate by 
cooling, shading and increasing air humidity. At the city level trees help to reduce the urban heat island. Plants provide stormwater runoff reduction due to water absorption by root systems and this prevents its drainage into the sewer system. They prevent erosion by fixing soils with root systems. Plants also increase biodiversity as they act as a habitat and source of food for other organisms.

Lin et al. [2016] showed that vegetation barriers $4-8 \mathrm{~m}$ in height and 2-6 $\mathrm{m}$ thick consisting of trees with foliage may reduce ultrafine particles (UFP) and CO concentration by 37.7-63.6\% and $23.6-56.1 \%$ behind the barriers on the downwind side of the road. During winter periods when foliage is reduced, a significant change in UFP and CO was not observed.

Surprisingly, the wrong configuration of street barriers may deteriorate the air quality behind them. It is especially applicable for street canyons - roads with attached buildings on both sides of the road.

Abhijith et al. [2017] show that most streetcanyons research revealed an increase of pollutant concentration for roadside areas with trees compared to those without trees. The reason for the negative effects of trees is the reduction of wind velocity in the street canyon, resulting in pollutant accumulation within the canyon. Such parameters as meteorological conditions (especially wind direction), the ratio of the height of buildings along roads to road width, specifics of the urban landscape and characteristics of the vegetation barriers significantly affect the pollutant removal process.

The general optimal variant, hedges (approximately $2 \mathrm{~m}$ in height) or separately standing trees are recommended for street canyons (Fig. 4).

Other options are green roofs and green walls. Studies related to these are not numerous but in general the research agrees that there is a reduction of pollutants in the roadside air compared to other vegetation forms which affect mainly the improvement of climatic conditions near roads. Due to higher costs their application is quite difficult. For areas with limited space for tree planting green roofs and green walls could be a promising option for the mitigation of air pollutants.

Solid barriers (noise barriers). Solid barriers are structures of tall flat panels installed along roads to mitigate transport noise and pollutants (Fig. 3). PM reduction behind the barriers occurs by means of the dispersion process - the deflection and deceleration of air flows coming from the road.

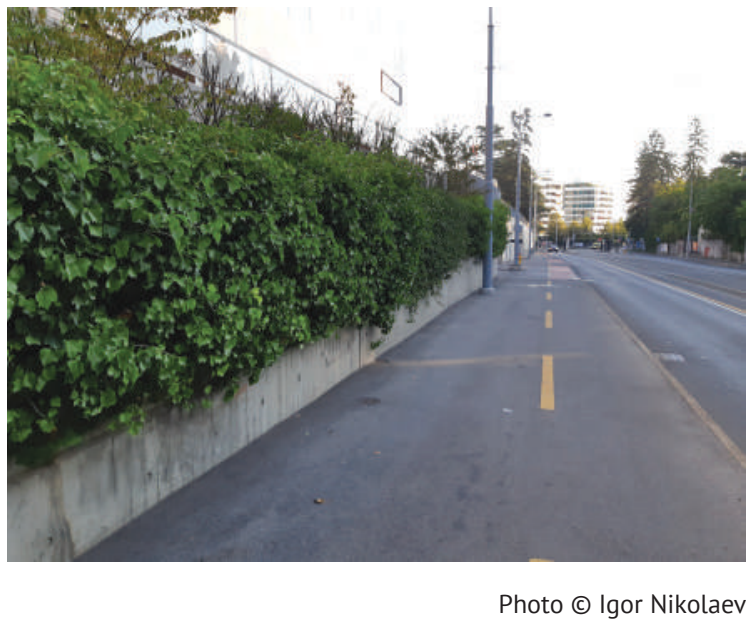

Fig. 4. Example of vegetation barriers in street canyon - Route de Chancy (Geneve, Switzerland)

Studying an Interstate highway of 125,000 vehicles per day (I-440) in Raleigh, North Carolina, Baldauf et al. [2008] reported that solid noise barriers $6 \mathrm{~m}$ in height placed $5 \mathrm{~m}$ from the road edge provide a $50 \%$ reduction of $\mathrm{PM}$ and a $15 \%$ reduction of $\mathrm{CO}$.

The disadvantage of solid barriers compared to tree barriers is a possible increase of pollutant concentration on the road. This happens due to the blocking of the deposition process which may be realized only by plant foliage.

Combinations of green and solid barriers. The presence of mature trees in addition to solid barriers leads to further decreases of PM. Many researches highlight vegetation-solid barrier combinations as another viable option to vegetation barriers [Tong et al., 2016].

Barriers along roads are a useful solution for transport-related contaminants. To achieve maximal efficiency of roadside air cleaning, barriers should be designed taking into account local characteristics.

\section{Conclusions}

1. Road transport creates a spectrum of contaminants affecting the environment and causing adverse health effects. Most vehicle emissions are in cities which makes the road traffic there a key source of environmental pollution.

2. Areas within $0-300 \mathrm{~m}$ from 4 lane roads are the zones of the highest human health risk.

3. Different solutions exist to decrease the negative effects of road transport on people 
and the environment: the reduction of vehicle emissions via improvements in fuel and the development of vehicle technologies; traffic management decisions to decrease the number of vehicles; the regulation of driving patterns; ecologically friendly road and roadside territory design.

\section{References}

Abhijith K.V. et al. (2017) Air Pollution Abatement Performances of Green Infrastructure in Open Road and Built-up Street Canyon Environments - A Review. Atmospheric Environment, vol. 162, pp. 71-86.

American Lung Association (2018) Living Near Highways and Air Pollution. Available at: http://www.lung.org/ our-initiatives/healthy-air/outdoor/air-pollution/ highways.html (accessed 16 September 2018).

Australian Government (2005) Nitrogen Dioxide $\left(\mathrm{NO}_{2}\right)$. Air Quality Fact Sheet. Department of the Environment and Energy. Available at: http://www.environment.gov.au/protection/publications/factsheet-nitrogen-dioxide-no2 (accessed 16.09.2018).

Babisch W. (2002) The Noise/Stress Concept: Risk Assessment and Research Needs. Noise Health, vol. 4, no 16, pp. 1-11.

Baldauf R. et al. (2008) Impacts of Noise Barriers on Near-road Air Quality. Atmospheric Environment, vol. 42, no 32, pp. 7502-7507.

Chen H. et al. (2017) Living Near Major Roads and the Incidence of Dementia, Parkinson's Disease, and Multiple Sclerosis: A Population-based Cohort Study. The Lancet, vol. 389, no 10070, pp. 718-726.

DieselNet. Emission standards. EU: Cars and Light Trucks. Available at: https://www.dieselnet.com/standards/ eu/ld.php (accessed 16 September 2018).

Enda M., Owen D. (2018) Population Exposure to Road Traffic Noise: Experimental Results from Varying Exposure Estimation Approaches. Transportation Research. Part D, vol. 58, pp. 70-79.

Federal Law of the Russian Federation N 34-FZ (2003) On Restriction of Turnover of Leaded Gasoline in the Russian Federation. Moscow.

Forman R.T.T. (2014) Urban Ecology. Science of Cities. Cambridge: Cambridge University Press.

Gałuszka A.et al. (2011) The Influence of Chloride Deicers on Mineral Nutrition and the Health Status of Roadside Trees in the City of Kielce, Poland. Environ Monit Assess, vol. 176, pp. 451-464.

Gennadiev A. et al. (2015) Hydrocarbonsinsoils: Origin, Composition, and Behavior (review). Eurasian Soil Science, vol. 48, pp. 1195-1209.

Green Car Report (2014) 1.2 Billion Vehicles On World's Roads Now, 2 Billion By 2035: Report. Available at:
4. To speed up the improvement of the ecological situation in cities the influence of traffic on the environment and human health should be recognized and familiar to citizens. A comprehensive system of ecological education from kindergarten to university should be organized.

https://www.greencarreports.com/news/1093560_12-billion-vehicles-on-worlds-roads-now-2-billionby-2035-report (accessed 16 September 2018).

Grimmer G. (1983) Environmental Carcinogens: Polycyclic Aromatic Hydrocarbons. CRC Press, Boca Raton.

Laumbach R., Kipen H. (2012) Respiratory Health Effects of Air Pollution: Update on Biomass Smoke and Traffic Pollution. Journal of Allergy and Clinical Immunology, vol. 129, pp. 3-11.

Lin M.Y. et al. (2016) The Effects of Vegetation Barriers on Near-road Ultrafine Particle Number and Carbon Monoxide Concentrations. The Science of the Total Environment, vol. 553, pp. 372-379.

Lu Y. et al. (2007) Chemical Fractionation of Heavy Metals in Urban Soils of Guangzhou, China. Environ Monit Assess, vol. 134, pp. 429-439.

Nikolaeva O., Rozanova M., Karpukhin M. (2017) Distribition of Traffic-related Contaminants in Roadside Soils Across a Highway in Moscow. Journal of Soils and Sediments, vol. 17, no 4, pp. 1045-1053.

Raaschou-Nielsen O. et al. (2012) Traffic Air Pollution and Mortality from Cardiovascular Disease and All Causes: a Danish Cohort Study. Environmental Health, vol. 11, p. 60. Available at: http://doi.org/10.1186/ 1476-069X-11-60 (accessed 16 September 2018).

Takada H. et al. (1991) Distribution and Sources of Polycyclic Aromatic Hydrocarbons (PAHs) in Street Dust from Tokyo Metropolitan Area. Science Total Environ, vol. 107, pp. 45-69.

Tong Z. et al. (2016) Roadside Vegetation Barrier Designs to Mitigate Near-road Air Pollution Impacts. The Science of the Total Environment, vol. 541, pp. 920-927.

United Nations (2014) Population Division. 2014 Revision of the World Urbanization Prospects. Available at: http://www.un.org/en/development/desa/publications/2014-revision-world-urbanization-prospects.html (accessed 16 September 2018).

US EPA (2014) Near Roadway Air Pollution and Health: Frequently Asked Questions. Office of Transportation and Air Quality EPA-420-F-14-044. Available at: https://nepis.epa.gov/Exe/ZyPDF.cgi/P100NFFD. PDF?Dockey=P100NFFD.PDF (accessed 16 September 2018). 
US EPA (United States Environmental Protection Agency). Nitrogen Dioxide (NO2) Pollution. Basic Information about NO2.Available at: https://www.epa.gov/no2-pollution/basic-information-about-no2\#What\%20is\%20 NO2 (accessed 16.09. 2018).

US EPA (United States Environmental Protection Agency). (2014) Priority Pollutant List.Available at: https:// www.epa.gov/sites/production/files/2015-09/documents/priority-pollutant-list-epa.pdf (accessed 16.09.2018).

US EPA (United States Environmental Protection Agency). (2014) Report on the Environment. Available at: https://cfpub.epa.gov/roe/indicator_pdf.cfm?i=23 (accessed 16 September 2018).

Van Bohemen H.D., Van De Laak W.H.J. (2003) The Influence of Road Infrastructure and Traffic on Soil, Water, and Air Quality. Environ Manag., vol. 31, pp. 50-68.

Vette A. et al. (2013) Community Action Against Asthma Steering Committee. The Near-Road Exposures and Effects of Urban Air Pollutants Study (NEXUS): Study Design and Methods. The Science of the Total Environment, vol. 448, pp. 38-47.

Werkenthin M., Kluge B., Wessolek G. (2014) Metals in European Roadside Soils and Soil Solution - A Review. Environ Pollut, vol. 189, pp. 98-110.
WHO (World Health Organization). (2006) Air Quality Guidelines for Particulate Matter, Ozone, Nitrogen Dioxide and Sulphur Dioxide. Global Update 2005, 2006. Available at: http://apps.who.int/iris/ bitstream/handle/10665/69477/WHO_SDE_PHE_ OEH_06.02_eng.pdf; jsessionid=3DA5BB2E5F04D9CC87A18204056DEBF7?sequence $=10$ (accessed 16 September 2018).

WHO (World Health Organization). (2011) Burden of Disease from Environmental Noise: The WHO European Centre for Environment and Health. Bonn Office. Available at: http://www.euro.who.int/_dataassets/ pdf_file/0008/136466/e94888.pdf (accessed 16 September 2018).

WHO (World Health Organization). (2000) Chapter 5.5. Carbon Monoxide. Available at: http://www. euro.who.int/_data/assets/pdf_file/0020/123059/ AQG2ndEd_5_5carbonmonoxide.PDF (accessed 16 September 2018).

WHO (World Health Organization). (2005) Health-effects of Transport-related Air Pollution / M. Krzyzanowski, B. Kuna-Dibbert, J. Schneider (eds). Available at: http://www.euro.who.int/__data/assets/pdf_file/ 0006/74715/E86650.pdf (accessed 16.09.2018). 


\section{АВТОТРАНСПОРТ КАК КЛЮЧЕВОЙ ИСТОЧНИК ЗАГРЯЗНЕНИЯ ОКРУЖАЮЩЕЙ СРЕДЫ \\ В ГОРОДАХ И РИСКИ ДЛЯ ЗДОРОВЬЯ ЛЮДЕЙ (ОБЗОРНАЯ СТАТЬЯ)}

Николаева Ольга Вячеславовна, кандидат биологических наук, старший научный сотрудник Учебно-опытного почвенноэкологического центра МГУ имени М.В. Ломоносова; Российская Федерация, 141592, Солнечногорский район, п. Чашниково, тел. +7 (926) 588-33-98

E-mail: olgamsu@yandex.ru

Сложно переоценить роль автотранспорта в жизни современного человека. Однако именно автотранспорт является ключевым источником загрязнения окружающей среды в городах, на его долю приходится 57-75\% суммарных выбросов загрязняющих веществ в атмосферу [WHO, 2005]. К сожалению, в России этой проблеме уделяется недостаточно внимания.

В данной обзорной статье рассматриваются механизмы образования загрязняющих веществ и особенности их распространения, обсуждаются риски для здоровья людей и представлены возможные решения для их минимизации.

Практическая польза: Автор ставит целью привлечь внимание представителей научных и образовательных учреждений, правительства и бизнеса к этой проблеме. Данный обзор поможет урбанистам учесть негативные эффекты влияния автотранспорта на качество жизни людей при планировании городской среды.

Ключевые слова: автотранспорт; загрязнение окружающей среды; риски для здоровья; город; урбоэкосистема

Цитирование: Nikolaeva O. (2018) Review: Road Transport as the Key Source of Environmental Pollution in Cities, and the Associated Human Health Risks. Urban Studies and Practices, vol. 3, no 3, pp. 25-35. DOI: https://doi.org/10.17323/usp33201825-35

\section{Источники}

Abhijith K.V. et al. (2017) Air Pollution Abatement Performances of Green Infrastructure in Open Road and Built-up Street Canyon Environments - A Review // Atmospheric Environment. Vol. 162. P. 71-86.

American Lung Association (2018) Living Near Highways and Air Pollution. Режим доступа: http://www.lung. org/our-initiatives/healthy-air/outdoor/air-pollution/highways.html (дата обращения: 16.09.2018).

Australian Government (2005) Nitrogen Dioxide $\left(\mathrm{NO}_{2}\right)$. Air Quality Fact Sheet. Department of the Environment and Energy. Режим доступа: http://www.environ- ment.gov.au/protection/publications/factsheet-nitrogen-dioxide-no2 (дата обращения: 16.09. 2018).

Babisch W. (2002) The Noise/Stress Concept: Risk Assessment and Research Needs // Noise Health. Vol. 4. No. 16. P. 1-11.

Baldauf R. et al. (2008) Impacts of Noise Barriers on Near-road Air Quality // Atmospheric Environment. Vol. 42. No. 32. P. 7502-7507.

Chen H. et al. (2017) Living Near Major Roads and the Incidence of Dementia, Parkinson's disease, and Multiple Sclerosis: A Population-based Cohort Study // The Lancet. Vol. 389. No. 10070. P. 718-726.

DieselNet. Emission Standards. EU: Cars and Light Trucks. Режим доступа: https://www.dieselnet.com/ standards/eu/ld.php (дата обращения: 16.09.2018).

Enda M., Owen D. (2018) Population Exposure to Road Traffic Noise: Experimental Results from Varying Exposure Estimation Approaches // Transportation Research. Part D. Vol. 58. P. 70-79.

Federal Law of the Russian Federation N 34-FZ (2003) On Restriction of Turnover of Leaded Gasoline in the Russian Federation. Moscow.

Forman R.T.T. (2014) Urban Ecology. Science of Cities. Cambridge University Press.

Gałuszka A.et al. (2011) The Influence of Chloride Deicers on Mineral Nutrition and the Health Status of Roadside Trees in the City of Kielce, Poland // Environ Monit Assess. Vol. 176. P. 451-464.

Gennadiev A. et al. (2015) Hydrocarbonsinsoils: origin, composition, and behavior (review) // Eurasian Soil Science. Vol. 48. P. 1195-1209.

Green Car Report (2014) 1.2 Billion Vehicles On World's Roads Now, 2 Billion By 2035: Report. Peжим доступа: https://www.greencarreports.com/ news/1093560_1-2-billion-vehicles-on-worldsroads-now-2-billion-by-2035-report (дата обращения: 16.09.2018).

Grimmer G. (1983) Environmental Carcinogens: Polycyclic Aromatic Hydrocarbons. CRC Press, Boca Raton.

Laumbach R., Kipen H. (2012) Respiratory Health Effects of Air Pollution: Update on Biomass Smoke and 
Traffic Pollution // J Allergy Clin Immunol. Vol. 129. P. 3-11.

Lin M.Y. et al. (2016) The Effects of Vegetation Barriers on Near-road Ultrafine Particle Number and Carbon Monoxide Concentrations //The Science of the Total Environment. Vol. 553. P. 372-379.

Lu Y. et al. (2007) Chemical Fractionation of Heavy Metals in Urban Soils of Guangzhou, China // Environ Monit Assess. Vol. 134. P. 429-439.

Nikolaeva O., Rozanova M., Karpukhin M. (2017) Distribition of Traffic-related Contaminants in Roadside Soils Across a Highway in Moscow // Journal of Soils and Sediments. Vol. 17. No. 4. P. 1045-1053.

Raaschou-Nielsen O. et al. (2012) Traffic Air Pollution and Mortality from Cardiovascular Disease and All Causes: A Danish Cohort Study // Environmental Health. Vol. 11. Р. 60. Режим доступа: http://doi. org/10.1186/1476-069X-11-60 (дата обращения: 16.09.2018).

Takada H. et al. (1991) Distribution and Sources of Polycyclic Aromatic Hydrocarbons (PAHs) in Street Dust from Tokyo Metropolitan Area // Science Total Environ. Vol. 107. P. 45-69.

Tong Z. et al. (2016) Roadside Vegetation Barrier Designs to Mitigate Near-road Air Pollution Impacts // The Science of the Total Environment. Vol. 541. P. 920-927.

United Nations (2014) Population Division. 2014 revision of the World Urbanization Prospects, 2014. Режим доступа: http://www.un.org/en/development/desa/ publications/2014-revision-world-urbanization-prospects.html (дата обращения: 16.09.2018).

US EPA (2014) Near Roadway Air Pollution and Health: Frequently Asked Questions. Office of Transportation and Air Quality EPA-420-F-14-044. Режим доступа: https://nepis.epa.gov/Exe/ZyPDF.cgi/P100NFFD.PDF?Dockey=P100NFFD.PDF (дата обращения: 16.09. 2018).

US EPA (United States Environmental Protection Agency). Nitrogen Dioxide (NO2) Pollution. Basic Information about NO2. Режим доступа: https:// www.epa.gov/no2-pollution/basic-informationabout-no2\#What\%20is\%20NO2 (дата обращения: 16.09.2018).
US EPA (United States Environmental Protection Agency). Priority pollutant list. (2014) Режим доступа: https:// www.epa.gov/sites/production/files/2015-09/documents/priority-pollutant-list-epa.pdf (дата обращения: 16.09.2018).

US EPA (United States Environmental Protection Agency) (2014) Report on the Environment. Режим доступа: https://cfpub.epa.gov/roe/indicator_pdf.cfm?i=23 (дата обращения: 16.09.2018).

Van Bohemen H.D., Van De Laak W.H.J. (2003) The Influence of Road Infrastructure and Traffic on Soil, Water, and Air Quality // Environ Manag. Vol. 31. P. 50-68.

Vette A. et al. (2013) Community Action Against Asthma Steering Committee.The Near-Road Exposures and Effects of Urban Air Pollutants Study (NEXUS): Study design and methods // The Science of the Total Environment. Vol. 448. P. 38-47.

Werkenthin M., Kluge B., Wessolek G. (2014) Metals in European Roadside Soils and Soil Solution - A Review // Environ Pollut. Vol. 189. P. 98-110.

WHO (World Health Organization). (2006) Air Quality Guidelines for Particulate Matter, Ozone, Nitrogen Dioxide and Sulphur Dioxide. Global Update 2005, 2006. Режим доступа: http://apps.who.int/ iris/bitstream/handle/10665/69477/WHO_SDE_ PHE_OEH_06.02_eng.pdf;jsessionid=3DA5BB2E5F04D9CC87A18204056DEBF7?sequence=10 (дата обращения: 16.09.2018).

WHO (World Health Organization). (2011) Burden of Disease from Environmental Noise: The WHO European Centre for Environment and Health. Bonn Office. Режим доступа: http://www.euro.who.int/_ dataassets/pdf_file/0008/136466/e94888.pdf (дата обращения: 16.09.2018).

WHO (World Health Organization). (2000) Chapter 5.5. Carbon Monoxide. Режим доступа: http://www. euro.who.int/_data/assets/pdf_file/0020/123059/ AQG2ndEd_5_5carbonmonoxide.PDF (дата обращения: 16.09.2018).

WHO (World Health Organization). (2005) Health-effects of Transport-related Air Pollution / M. Krzyzanowski, B. Kuna-Dibbert, J. Schneider (eds). Режим доступа: http://www.euro.who.int/__data/assets/ pdf_file/0006/74715/E86650.pdf (дата обращения: 16.09.2018). 